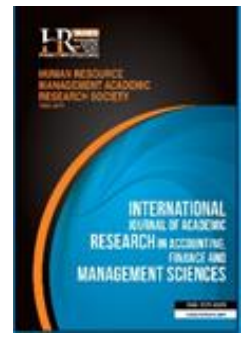

International Journal of Academic Research in Accounting, Finance and Management Sciences

Vol. 8, No.4, October 2018, pp. 21-29

E-ISSN: 2225-8329, P-ISSN: 2308-0337

(c) 2018 HRMARS

www.hrmars.com

To cite this article: Samail, N.A.B., Zaidi, N.S.B., Mohamed, A.S.b, Kamaruzaman, M.N.b. (2018). Determinants of Financial Performance of Islamic Banking in Malaysia, International Journal of Academic Research in Accounting, Finance and Management Sciences 8 (4): 21-29.

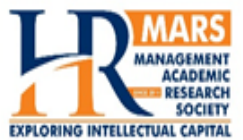

http://dx.doi.org/10.6007/IJARAFMS/v8-i4/5182 (DOI: 10.6007/IJARAFMS/v8-i4/5182)

\title{
Determinants of Financial Performance of Islamic Banking in Malaysia
}

\author{
Nur Amirah Binti SAMAIL ${ }^{1}$, Nurul Syuhada Binti ZAIDI ${ }^{2}$, \\ Ahmad Syubaili b MOHAMED ${ }^{3}$, Mohd Naim bin KAMARUZAMAN ${ }^{4}$ \\ 1,2,3,4 Faculty Economics and Business, University Malaysia Sarawak (UNIMAS), \\ ${ }^{1}$ E-mail: amirasamail@gmail.com, ${ }^{2} E$-mail: znsyuhada@unimas.my, \\ ${ }^{3}$ E-mail: masyubaili@unimas.my, ${ }^{4} E$-mail: kmnaim@unimas.my
}

\begin{abstract}
This research was conducted to investigate the determinants of the financial performance of Islamic banking in Malaysia. The performance of Islamic Bank measured based on return on asset (ROA), while the independent variables examined were capital adequacy (CA), asset quality (AQ), and liquidity management (LM). The data for this research were collected from twelve out of sixteen Islamic Banks in Malaysia listed by Bank Negara Malaysia. The annual reports were analyzed for six years which were from the year 2010 until 2016. The findings revealed that there is a significant relationship between asset quality and liquidity management towards the performance of Islamic Banking in Malaysia. However, there is insignificant relationship between capital adequacies towards the performance of Islamic Banking in Malaysia. Nevertheless, there are still other factors that may affect the performance of Islamic Banking in Malaysia.
\end{abstract}

Key words Islamic Banking, Return on Asset, capital adequacy, liquidity management, asset quality

Received: 25 Nov $2018 \quad$ C The Authors 2018

Revised: 5 Dec 2018 Published by Human Resource Management Academic Research Society (www.hrmars.com)

Accepted: 12 Dec 2018 This article is published under the Creative Commons Attribution (CC BY 4.0) license. Anyone may reproduce, distribute, translate and create derivative works of this article (for both commercial and noncommercial purposes), subject to full attribution to the original publication and authors. The full terms of this license may be seen at: http://creativecommons.org/licences/by/4.0/legalcode

\section{Introduction}

Every country has financial institutions to embody the financials guidelines and ensure the economic growth as well as, control of money for the country. The financial institutions are responsible to manage and control all the resources related to financing. The presence of banking institution is to help the growth of economic activity in a country. In Malaysia, there are currently three types of banking institution which are conventional banking, investment banking and Islamic banking.

Conventional banking and investment banking are considered under the commercial banking guidelines meanwhile, Islamic banking falls under its own category. The banking system is also a financial institution or agency for the public to save funds in the forms of savings or in the form of credit to improve living standards while keeping their money in the banks. Other than that, the banking system also functions as a supplier of the money and funding money to help the economic activities in Malaysia. Alternatively, an investment bank deals with money and credit for profit-seeking business firm.

Additionally, Islamic Banks perform the same purposes as commercial banks, but Islamic banking obligation follows the rules of Islamic Shariah board. Malaysia is the one of the fastest growing countries in the Islamic finance industry. The existing Islamic banking system in Malaysia has received numerous recognitions and become references to other countries. Islamic banking was based on the Islamic Law as 
the main guideline, where the Shariah Law was followed to conduct business with sharing profit and loss concept and prevention of interest or Riba (Jalil and Rahman, 2010).

Islamic finance has grown massively since the introduction of the Islamic Development Bank by the Organization of Islamic Countries (OIC) in the 1970's. That has led to the establishment of the Islamic financial system in Malaysia in 1983. By the end of 2017, the number of Islamic banks in Malaysia has expanded to 16 banks from only 2 banks in 2001 (Bank Negara Malaysia, 2017). Before the establishment of the Islamic financial system, conventional banks play a significant role in the global financial environment. In 2011, Islamic finance has become the fastest growing sector in the global financial industry with about $20 \%$ growth yearly (Kuwait Finance House, 2013).

The performance of the financial system has big influences on the growth of Islamic banking. According to previous study, financial performance plays an important role in the economic in the whole country (Blejer, 2006). Thus, in this research we will determine the variables that will affect the financial performance in Islamic Banking. This research will use data from the Islamic Banks in Malaysia.

During the global financial crisis, some banks experienced difficulties because they failed to manage liquidity in a prudent manner. The crisis emphasized the importance of liquidity to have an effective financial markets and banking sector. The rapid reversal in market situations enlightened the way liquidity can quickly soften the impact. From previous research, Bourke (1989) discovered a positive significant relationship between profitability and bank liquidity. However, the research from Thornton and Molyneux (1992) concluded that there is a negative correlation between profitability levels and liquidity.

According to Zingales and Hart (2009), banks must hold more capital to have a good financial performance. However, there some researcher argues that if bank holds too much capital, this may negatively affect the financial performance especially in terms of profitability since the capital can better used to make other investment. The efficiency and profitability of Islamic banks in the Arab countries research by lqbal and Molyneux (2005), concluded that when the cost of inefficiency is the same, then the inefficiency advantage will vary. This is because situation of Islamic banks will usually reflect different services.

\subsection{Research Objective}

The main objective of this study is to investigate the determinants of financial performance of Islamic Banking in Malaysia. This study specifically addresses the following objectives:

I. To examine the relationship between capital adequacy (CA) on Return on Asset (ROA) of Islamic banking in Malaysia.

II. To examine the relationship between Asset Quality ( $\mathrm{AQ}$ ) on Return on Asset (ROA) of Islamic banking in Malaysia.

III. To examine the relationship between Liquidity Management (LM) on Return on Asset (ROA) of Islamic banking in Malaysia.

\subsection{Research Hypothesis}

To investigate the above objectives, the following hypotheses were formulated:

\section{Hypothesis 1}

$\mathrm{H}_{0}$ : There is no significant relationship between capital adequacy and return on asset that affect the performance of Islamic banking In Malaysia.

$\mathrm{H}_{1}$ : There is a significant relationship between capital adequacy and return on asset that affect the performance of Islamic banking In Malaysia.

\section{Hypothesis 2}

$\mathrm{H}_{0}$ : There is no significant relationship between asset quality and return on asset that affect the performance of Islamic banking In Malaysia.

$\mathrm{H}_{2}$ : There is a significant relationship between asset quality and return on asset that affect the performance of Islamic banking In Malaysia.

Hypothesis 3

$\mathrm{H}_{0}$ : There is no significant relationship between liquidity management and return on asset that affect the performance of Islamic banking In Malaysia. 
$\mathrm{H}_{3}$ : There is a significant relationship between liquidity management and return on asset that affect the performance of Islamic banking In Malaysia.

\section{Literature review}

The economic growth of the countries is built on the performance of financial sector. According to (Siraj and Pillai, 2012) the growth and economic stability depend on the stability of its banking sector. It helps in facilitating funds for productive purposes, contributing to economic development and acting as an intermediary in linking deficit and surplus unit. The previous study also found that management efficiency, risk weighted assets, and asset size have influences on Islamic banking credit risk, while conventional banking credit risk is influenced by loans exposed to risky sectors, capital regulation, risk weighted assets on credit risk and allocation of losses financing, S. Sodhi (2005). The management of assets and liabilities for a bank is very important by making a correct structuring and strategy (Manuji and Mentzer, 2008). According to Rosly and Abu Bakar (2003), the used of financial ratio of Islamic banks in Malaysia to show that profitability based on return on asset, profit margin and net profit margins was statically higher for Islamic banks in Malaysia. Islamic banking now expanded their banks size and operation globally and receives the attention from other Islamic and non-Islamic countries.

Nowadays, Islamic banking was being operated in almost every country and becoming an alternative system for conventional banking system. According to Jamali et al., (2012), the stakeholders such as general public, investors and customers are very important to the overall bank performance. The nature of bank profitability comes from two categories which are external and internal determinant. However, for this study, researchers will only focus on the internal determinants only which are return on asset, capital adequacy, liquidity and asset quality.

\subsection{Inception of Islamic Banking}

Islamic banking has received numerous acknowledgments and become references to other countries. With the existing products offered by Islamic banking in the market, it has given consumers the choice of selecting Islamic finance products. The community can select the banking system options that can avoid Riba, Gharar, Maysir and other prohibition in Islamic Finance. The implementation of the Islamic banking system in Malaysia has been proven to be successful through several approaches that include the dual banking system, comprehensive legal framework, capital market support and securities, monitoring and human resource policies. This integrated approach enables the implementation of the Islamic banking system to run smoothly and rapidly not only in the local arena but also internationally.

\subsection{Return on Asset}

According to Hafidz and Sulaiman (2011), return on asset (ROA) was used in measuring the influence of production of all capital that was invested in firms. The ROA also measures the ability of the firm to generate returns for every capital in investment asset (Hadi et al., 2014). According to Kristy and Susan (1984) return on asset is a good internal managing ratio because it measures profit against the entire asset a division uses to make those earnings. Hence, banks can use this way to evaluate the division's profitability and effectiveness of the financial performance. Other than that, Samad and Hassan (1999) have indicated that return on asset helps verifies how the banks are proficient to alter asset into net earnings or net profit. Islamic banks have brought a new innovation in the banking system with its existence underlying assets in the transaction. Durham (2003) examined the performance of banks and found that asset growth had a positive and significant effect. While Titman and Wessel (1988) found that asset growth had no significant effect on capital increase. The bigger the size of the bank, with addition to a lower deposit rate will lead to the higher profit and higher obtaining power (Flamini et al., 2009).

\subsection{Asset Quality}

According to Ismail (2010), asset quality illustrates bank asset quality levels. The increase in this ratio is a serious and the bank needs to make provision of bad and problematic debt to cover losses from financing. Chaudhry and Sigh (2012), reviewed the changes in the quality of assets in banking in India using secondary data and the findings of the research shows that changes to the quality of assets had become a strong entity for the banking sector in India after the liberalization process. In addition, there has been a shift from 
more cost-effective management, sophisticated banking technology, the ability of the bank to be competitive.

De Bock and Demyanets (2012), discuss about the quality of bank assets in the open market. He used a set of data for 25 developing countries from 1996 to 2010 and found weak economic growth as a result of the economic downturn led to the collapse of capital flows and reduced credit growth and loan quality also deteriorated. Chisti (2012), in his study peeling on the impact of asset quality profits on private banks. This study focuses on the effect of loan quality on bank performance. Researchers used the profit ratio as a permanent variable for the years 2006 to 2007 and 2010 to 2011. The findings found that there was no relationship between the asset ratio. One decision has supported the study's hypothesis that higher quality in loan processing before loan approval can improve the performance of banking operations.

\subsection{Liquidity Management}

Mounira and Anas (2008), stated about the liquidity management is a very big issue for all banks in Malaysia and also to the regulatory body of the bank. There are so many risks that the Islamic bank should take note of. Liquidity risk management is important in the banking environment. The banking institution today also faced with the risk arising from the natural risk as a result of the use of profit and loss sharing. This study discusses how Islamic banks are facing liquidity risk. Driga (2009) discusses liquidity management of banking institution and found the results show the liquidity management are included in the assessment of inflows cash bank against outflows and liquidity assessment of assets to identify potential against lack of funds. All the bank needs to identify the liquidity risks exposed and need to identify the relationship between liquidity risk and the type of risk exposed.

\subsection{Capital Adequacy}

The higher the capital adequacy ratio (CAR) is, the better the ability of the bank to bear the risk. If the value of CAR is high then the bank is able to finance operating activities and make a substantial contribution to profit. According to Lukman (2000) capital adequacy ratio is a ratio which shows how far all bank assets containing risk such as credit, marketable securities, bills in other banks are partly funded by the bank's own capital funds besides raising funds from sources outside the bank such as public funds or loans. CAR also is an indicator of the ability of the bank to cover decline in its assets as a results of bank losses caused by risky assets.

\section{Methodology of research}

This research retrieves data from the years of 2010 until 2015 from Bank Negara Malaysia and the annual financial report of 12 Islamic Banks in Malaysia. In this study, Return on Asset (ROA) will be used to identify the performance of the Islamic Banks. Hence, ROA will act as the dependent variable. Meanwhile, asset quality, liquidity and capital adequacy will be used as the independent variable.

The table below shows the list of the Islamic banking in Malaysia that has been chosen in from Bank Negara Malaysia (BNM).

Table 1. List of Islamic Banks in Malaysia

\begin{tabular}{|c|l|}
\hline No. & \multicolumn{1}{|c|}{ Name of Islamic Banks in Malaysia } \\
\hline 1 & Al Rajhi Banking \& Investment Corportation (Malaysia) Berhad \\
\hline 2 & Alliance Islamic Bank Berhad \\
\hline 3 & Bank Islam Malaysia Berhad \\
\hline 4 & AmBank Islamic Berhad \\
\hline 5 & Affin Islamic Bank Berhad \\
\hline 6 & Hong Leong Islamic Bank Berhad \\
\hline 7 & Public Islamic Bank Berhad \\
\hline 8 & CIMB Islamic Bank Berhad \\
\hline 9 & Kuwait Finance House (Malaysia) Berhad \\
\hline 10 & OCBC Al-Amin Bank Berhad \\
\hline 11 & HSBC Amanah Malaysia Berhad \\
\hline 12 & RHB Islamic Bank Berhad \\
\hline
\end{tabular}


The empirical model applied in this study is according to the past research that is in line with the objective to examine the determinants of financial performance. In previous study, (Ongore and Kusa, 2013) used several variables in their studies to determine the financial performance of Commercial Banks in Kenya. The firm-specific variables included in this study are common and significance variables that applied in financial performance of banks literature. Hence, the empirical model to be examined in this study is expressed as follow:

$$
\pi_{i t}=\beta_{0}+\beta_{1} C A_{i t}+\beta_{2} A Q_{i t}+\beta_{3} L M_{i t}+\varepsilon_{i t}
$$

Where,

$\begin{array}{ll}\pi_{i t} & \text { Performance of Bank } \mathrm{i} \text { at time } \mathrm{t} \text { as expressed by ROA } \\ C A_{i t} & \text { Capital Adequacy of bank } \mathrm{i} \text { at time } \mathrm{t} \\ A Q_{i t} & \text { Asset Quality of bank } \mathrm{i} \text { at time } \mathrm{t} \\ L M_{i t} & \text { Liquidity Management of bank } \mathrm{i} \text { at time } \mathrm{t} \\ \varepsilon_{i t} & \text { Error term }\end{array}$

The dependent variable, performance of bank is measured by return on asset (ROA) and it is computed by calculating the profit before taxation divided by total asset. The return on assets is an indicator of managerial efficiency since it measures the management's capability of converting the bank's assets into net earnings. The definition and proxy measurement for dependent and independent variables is summarized in Table 2.

Table 2. Definition and proxy measurement for study variables

\begin{tabular}{|c|c|}
\hline Variables & Definition/Proxy measurement \\
\hline \multicolumn{2}{|l|}{ Independent variables } \\
\hline $\begin{array}{l}\text { Capital Adequacy } \\
\text { (CA) }\end{array}$ & $\begin{array}{l}\text { Capital Adequacy demonstrates the ability of banks to maintain capital adequate and } \\
\text { internal bank management capabilities identifying, measuring, monitoring and controlling } \\
\text { risks which might affect the bank's total capital. The capital adequacy formula is as follows: } \\
\text { Capital Adequacy }=\frac{\text { Total Capital }}{\text { Total Assets }}\end{array}$ \\
\hline $\begin{array}{l}\text { Asset Quality } \\
\text { (AQ) }\end{array}$ & $\begin{array}{l}\text { Illustrates the levels of bank asset quality. } \\
\text { Non - performing loans }\end{array}$ \\
\hline & Asset Quality $=\frac{\text { Total loans }}{\text { Tot }}$ \\
\hline $\begin{array}{l}\text { Liquidity Management } \\
\text { (LM) }\end{array}$ & $\begin{array}{l}\text { To assess the liquidity of the banks, the long-term debt to total assets will be used, which } \\
\text { measures the amount assets that have been engaged in loans. } \\
\text { Total loans }\end{array}$ \\
\hline & Liquany management $=$ Total customer deposit \\
\hline \multicolumn{2}{|l|}{ Dependent variable } \\
\hline \multirow[t]{2}{*}{$\begin{array}{l}\text { Performance of Bank } \\
\qquad(\pi)\end{array}$} & $\begin{array}{l}\text { The return on assets is an indicator of managerial efficiency since it measures the } \\
\text { management's capability of converting the bank's assets into net earnings. } \\
\text { Profit before taxation }\end{array}$ \\
\hline & Total Asset \\
\hline
\end{tabular}

\section{Statistical Analysis}

\subsection{Panel Data Regression Analysis}

The first step taken to start this study is to identify the list of Islamic Banks in Malysia to get the sample. There are 16 Islamic Banks in Malaysia. However, for the purpose of this study only twelves Islamic banking in Malaysia will be taken to determine the financial performance of Islamic Banks (Table 1). The data was taken for the period of six years (2010 until 2015). The dependent variable used to measure Islamic Banking performance in this study is the Return on Asset (ROA), while the independent variables are Capital Adequacy (CA), Asset Quality (QA) and Liquidity Management (LM). Next, descriptive statistics will be 
carried out to analyze the behavior of the study variables in term of the mean and standard deviation for the purpose of empirical analysis. Apart from that, three panel data tests conducted in this study was the Pooled Ordinary Least Square (OLS), Random Effect Model and Fixed Effect Model. This panel data and test was used to check the relationship between return on asset and the three independent variables which is capital adequacy, asset quality and liquidity management. The tests were also conducted for the estimation analysis. Next, this study used the Breusch Pagan Lagrangian Multiplier Test to examine the most appropriate regression model between Pooled OLS and Random Effect Model. The Breusch Pagan Lagrangian Multiplier Test Result also to know which test is most efficient and proper for this research.

\subsection{Findings and discussions}

\subsubsection{Descriptive Statistics}

The summary of descriptive statistics for the panel data of 12 Islamic Banking in Malaysia is presented in Table 3. Table 3 shows the means, standard deviation, minimum and maximum values. The statistics indicate that the average mean of ROA representing the 12 Islamic banks in Malaysia is 1.043086 with a maximum of 5.351288. The average mean for asset quality with the least value of 0.231817 and an average mean of 2.743103. Liquidity management (LM) on the other hand has an average mean of 90.66559 and capital adequacy has the minimum mean of 11.73000 . The highest maximum average among those four variables would be liquidity management ratio (LM) with the amount of 196.8937 . For the standard deviation, dependent variable ROA comes out with 1.249819. Meanwhile, for the independent variable AQ, LM and CA end up by having the amount of standard deviation $4.341006,24.81700$ and 3.088662 respectively. The higher standard deviation is LM with the amount of 24.81700; which means that it has the greater volatility among the rest.

Table 3. Summary of descriptive statistics for dependent and independent variables

\begin{tabular}{|c|c|c|c|c|c|}
\hline Variables & Mean & Standard Deviation & Minimum & Maximum & Observation \\
\hline ROA & 1.043086 & 1.249819 & -5.336086 & 5.351288 & 72 \\
\hline AQ & 2.743103 & 4.341006 & 0.231817 & 28.61473 & 72 \\
\hline LM & 90.66559 & 24.81700 & 10.14307 & 196.8937 & 72 \\
\hline CA & 15.29403 & 3.088662 & 11.73000 & 27.18000 & 72 \\
\hline
\end{tabular}

Note: (1) ROA=Return on assets, $A Q=A s s e t$ Quality, $L M=$ Liquidity Management, $C A=$ Capital Adequacy

\subsubsection{Panel Data Regression Analysis}

Table 4 shows the result of panel data regression analysis for Return on Assets (ROA) as dependent variables. The three panel data modes was conducted in this study is Pooled Ordinary Least Square (OLS), Random Effect Model and Fixed Effect Model. The panel data analysis for pooled OLS model shows the independent variable which was asset quality, liquidity management, capital adequacy while the dependent variable is return on asset (ROA). The asset quality result shows the negative relationship with dependent variable which is ROA when the coefficient is -0.162257 .

Table 4. The Result of Panel Data Regression Analysis of ROA and independent variables

\begin{tabular}{|l|c|c|c|}
\hline & Pooled OLS & Random Effect & Fixed Effect \\
\hline AQ & -0.162257 & -0.201623 & -0.357223 \\
& $(-4.9843)$ & $(-6.5149)$ & $(-6.9014)$ \\
\hline LM & 0.014007 & 0.016118 & 0.008192 \\
& $(2.4128)$ & $(3.0451)$ & $(-0.1476)$ \\
\hline CA & 0.083530 & 0.082780 & -0.008592 \\
& $(1.6901)$ & $(1.8458)$ & $(-0.1476)$ \\
\hline R-Square & 0.300016 & 0.391966 & 0.620368 \\
\hline F-statistics & 9.715013 & 14.61194 & 6.653248 \\
\hline
\end{tabular}

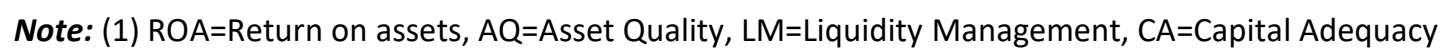


Hence, the other two independent variable which is liquidity management and capital adequacy shows the positive relationship of return on asset (ROA) with the result of coefficient is 0.014007 and 0.083530 . The positive relationship shows that capital adequacy and liquidity management give the impact to financial performance on Islamic Banking in Malaysia. The result of pooled OLS on asset quality shows there is significant relationship between the return of asset and assets quality because $p$ value $(0.000)$ is less than 0.05 significant levels. So, Pooled OLS test is rejecting the null hypothesis.

\subsubsection{Proposed Model Selection}

This study is using tests of Breusch Pagan Lagrangian Multiplier Test to examine the most appropriate regression model between Pooled OLS and Random Effect Model. In the Breusch Pagan Lagrangian Multiplier test the result in table 5 the $p$-value is 0.0145 . Since $p$-value less than 0.05 at $1 \%$ significant level, therefore this study is most efficient using the Random Effect Model.

Table 5. Breusch Pagan Lagrangian Multiplier Test Result

\begin{tabular}{|l|c|c|c|}
\hline \multicolumn{2}{|c}{ Cross-section } & Test Hypothesis Time & Both \\
\hline Breusch-Pagan & 5.717966 & 0.263630 & 5.981596 \\
\hline & $(0.0168)$ & $(0.6076)$ & $(0.0145)^{* * *}$ \\
\hline
\end{tabular}

Table 6. The Result of Random Effect Model

\begin{tabular}{|ccccc|}
\hline Variable & Coefficient & Std. Error & t-Statistic & Prob. \\
\hline \hline AQ & -0.201623 & 0.030948 & -6.514953 & 0.0000 \\
LM & 0.016118 & 0.005293 & 3.045075 & 0.0033 \\
CA & 0.082780 & 0.044848 & 1.845790 & 0.0693 \\
\hline
\end{tabular}

Note: (1) ROA=Return on assets, $A Q=A s s e t$ Quality, $L M=$ Liquidity Management, $C A=C a p i t a l$ Adequacy

The most preferable model for this research is the Random Effect Model. The data can be explained on Table 6. Based on this result, liquidity management and capital adequacy has a positive relationship with ROA. Based on table 6, liquidity management and capital adequacy has a positive relationship with ROA with coefficient is 0.016118 and 0.082780 respectively. The result is parallel with previous study done by Sangmi and Nazir (2010) on his research which investigate the performance of Islamic banking in Malaysia by using capital adequacy has an effect on the profitability of the banks.

$P$-value for asset quality is 0.0000 which is significant with ROA because the value of $p$-value is less than significance level $0.05 \%$. It is same with liquidity management which shows the positive significant when the $p$-value 0.0033 less than significance level. Asset quality and liquidity management has positive relationship with ROA. From the previous study, according to Dang (2011) the level of liquidity management is positively related to the bank performance, the bank must have an ability to fulfill the obligations to get a good financial performance.

The coefficient of asset quality (AQ) is -0.201623 shows that asset quality has a negatively significant with return on asset. In addition, the value of t-statistical also influence the asset quality of the banks which is the value is -6.514953 and this also shows the negative relationship with ROA. The asset qualities of the banks have a negative impact to the financial performance. In Random Effect Model, the p-value of asset quality 0.000 is less than 0.05 significance levels, therefore null hypothesis 1 rejected.

The liquidity management shows the positive relationship with the coefficient value to ROA is 0.016118 and the t-statistical value is 3.045075 . It indicates that the more loans from the customers it will increases the financial performance of the banks. Therefore, the total of loans on liquidity management will positively impact the financial performance of the banks. In Random Effect Model, the p-value of liquidity management 0.0033 is less than 0.05 significance levels, thus the null hypothesis 2 was rejected.

Next variables are capital adequacy, which also shows the positive relationship with ROA with coefficient value 0.082780 and t-statistics is 1.845790 . The variable of capital adequacy gives influence to the bank profitability. The capital adequacy will show the internal strength of the banks. Based on the previous study, Sangmi and Nazir (2010), capital adequacy has effect on the profitability of banks by determining the total capital to total asset. In Random Effect Model, the p-value of capital adequacy 0.0693 
which is more than 0.05 significance levels, subsequently accepts the null hypothesis 3 . From this study the answer for research objectives is below:

Objective 1: To determine relationship between the capital adequacy and return on asset has affected to the financial performance of Islamic banking in Malaysia. Capital adequacy has affected the ROA positively but not significantly. Capital adequacy also has a strong relationship with ROA when the coefficient estimates 0.0828 and $p$ - value is 0.0693 which is more than $5 \%$ confidence level. Capital adequacy highly correlated because Islamic banking need to have a strong financial in order to get more profit and the higher profit will cause a good financial performance to the banking sectors. In conclusion, this study found capital adequacy and return on asset have a relationship.

Objective 2: To determine relationship between the asset quality and return on asset has affected to the financial performance of Islamic banking in Malaysia. The asset had affected the ROA negatively but significantly. It can be proved that the coefficient for the asset quality by the ROA as dependent variables is -0.2016 , while coefficient level is less than 0.05 , which is 0.0000 . The Islamic banking must able to develop their asset in order to make a better profit from their investment that had been through.

Objective 3: To determine relationship between the liquidity management and return on asset has affected to the financial performance of Islamic banking in Malaysia. The liquidity of the banking sector also affected the ROA positively and significantly. The coefficient estimates for the liquidity management and return on asset is 0.0161 and significant values are 0.0033 , which significantly correlated each other. The conclusion is the liquidity management is very important to improve the financial performance in Islamic banking.

\section{Conclusions and recommendations}

This study investigated the financial performance on Islamic Banking in Malaysia for the period of six years, from 2010 until 2015. There were 12 Islamic banks chosen which were listed in Bursa Malaysia and panel data was used to analyse the findings of this data. To measure the performance of Islamic Bank, Return on Asset (ROA) was used as dependent variable to measure the performance. The independent variables were capital adequacy (CA), asset quality ( $A Q)$ and liquidity management (LM).

From this study, the findings show asset quality (AQ) has a significant relationship with ROA with the $p$ value is 0.000 which shows that asset quality is an important factor that impacted the performance of Islamic Banks in Malaysia. Other than that, and liquidity management has significant relationship with return on asset (ROA) because the $p$-value is 0.0185 less than 0.05 significance levels. The $p$-value of capital adequacy is 0.0956 more than 0.05 significance levels so there are insignificant relationships with return on asset (ROA). We reject $\mathrm{H}_{3}$ hypothesis because there is an insignificant relationship. In brief, Islamic Banking Industry plays an important role in the development of Malaysian's economy. Therefore, it is important to identify the factors that contribute the performance of Islamic Banks to ensure the sustainability of the industry and the country's economy.

\section{Acknowledgments}

The authors would like to thank for the financial support from Universiti Malaysia Sarawak (UNIMAS) and Research Grant Scheme F01/SpSTG/1577/2017. All remaining flaws are the responsibilities of the author.

\section{References}

1. Accounting Tools. (n.d.). Retrieved from Aggressive Accounting: http://www.accountingtools.com/ questions-and-answers/what-is-aggressive-accounting.html.

2. Bank Negara Malaysia. (2017). Retrieved December 1, 2017, from Financial Stability: http://www.bnm.gov.my/?ch=li\&cat=islamic\&type=IB\&lang=en

3. Blejer, M. I. (2006, December). Economic growth and the stability and efficiency of the financial sector. Journal of Banking \& Finance, 30(12), 3429-3432.

4. Board, I. (n.d.). Islamic Board. Retrieved from ljtihad, Qiyas \& ljma': https://www.islamicboard. com/-ilm-knowledge/134316084-ijtihad-qiyas-amp-ijma.html

5. Brouke, P. (1989). Concentration and other Determinants of Bank Profitability and Rates of Return Margins in Islamic Bank. Journal of Banking and Finance, 65-80. 
6. Cerutti, E., \& Ariccia, G. D. (2007). How banks go abroad: Branches or subsidiaries? Journal of Banking \& Finance, 1669-1692.

7. CIMB. (n.d.). Retrieved from CIMB: http://www.cimb.com/en/who-we-are/overview/history.html

8. Durham, J. B. (2003). Foreign portfolio investment, foreign bank lending, and economic growth. Journal of International Finance.

9. Ethical Values. (n.d.). Retrieved from BD Dictionary: http://www.businessdictionary.com/definition/ ethical-values.html

10. Flamini, V., Schumacher, L. M., \& McDonald, M. A. (2009). The determinants of commercial bank profitability in Sub-Sahran Africa. International Monetary Fund.

11. Hadi, A., F. S., Razak, A. A., Muhammad, F., Yusuf, Y. A., \& Mohd Hussin, M. M. (2014). Potentials of Islamic Real Estate Investment Trusts (I-REITs) in advancing oil palm industry in Malaysia. Journal of Society and Space, 10.

12. Hasan, Z. (2012, January 4). Corporate governance in Islamic financial institutions: An ethical perspective. Journals of Business Administration and Management (BAM), 2, 405-411.

13. HO, M. (n.d.). Poskod. my. Retrieved from Why is the value of ringgit falling: http://poskod.my/cheat-sheets/6-things-know-falling-ringgit-value/

14. Investopedia. (n.d.). Retrieved from Liquidity Ratios: http://www.investopedia.com/terms/l/ liquidityratios.asp

15. Iqbal, M., \& Molyneux, P. (2005). Thirty Years of Islamic Banking. New York: Palgrave Macmillan.

16. Ismail, G. A., \& Tohirin, A. (2010). Islamic law and finance. Journal of Islamic Law and Finance, 26, 178-199.

17. Jalil, D. M., \& Rahman, M. K. (2010, December). Financial Transactions in Islamic Banking are Viable Alternatives to the Conventional Banking Transactions. International Journal of Business and Social Business, 1(3), 219-230.

18. Kahn, C. M., \& Calomiris, C. W. (1991, Jun). The role of demandable debt in structuring optimal banking arrangements. Journal of Economics, 81, 497-513.

19. Karina, Y., \& Anggono, A. H. (2014). Determinants of capital adequacy requirements (CAR) for credit risk weighted assets on 19 conventional banks Indonesia period year 2008-2013. Proceedings of 7th AsiaPacific Business Research Conference.

20. Kuwait Finance House. (2013). Global Islamic Finance: Growth, Development \& Prospects.

21. Lin, L. B. (2012). Factors Affecting the Performance of Financial Sector in Malaysia.

22. Manuji, I., \& Mentzer, J. T. (2008). Global supply chain risk management strategies. Journal of Physical Distribution \& Logistic Management, 38, 192-223.

23. Muhammed, D. J., \& Al Nasser, S. A. (2013). Introduction to history of Islamic banking in Malaysia. In S. A. Al Nasser, \& D. D. Muhammed, Introduction to history of Islamic banking in Malaysia (pp. 80-87). Malaysia: Emerald Group Publishing Limited.

24. Omarini, A. $(2014,4)$. Strategy and business models in retail banking: Why they also matter to supervisors. Journal of Financial Transformation, 47-58.

25. Ongore, V. O., \& Kusa, G. B. (n.d.). Determinants of Financial Performance of Commercial Banks in Kenya. International Journal of Economics and Financial Issues, 237-252.

26. Rammal, H. G. (2006). The importance of Shariah supervision in Islamic financial institutions. Journal od Corporate Ownership and Control, 3, 204-208.

27. Shabbir, M.F., Aslam, D.H., Capusneanu, S., Barbu, C.M., Tanveer, M.A. (2012). Perceived service quality of Islamic and non Islamic banks operating in Pakistan, American Journal of Scientific Research 51, 27-36.

28. Shaun, C. (2017). My Accounting Course. Retrieved from http://www.myaccountingcourse.com/ financial-ratios/profitability-ratios.

29. Sudarsanan, P. P., \& K, K. S. (2012). Comparative study on performance of Islamic banks and conventional banks in GCC region. Journal of Applied Finance and Banking, 2(3), 123-161.

30. Thornton, J., \& Molyneux, P. (1992). Determinants of European bank profitability. Journal of Banking and Finance, 1173-1178.

31. Usman, M., \& Ghouri, N. T. (2014). Reasons and Causes that Prevent Customers from Buying Banking Products in Pakistan. International Journal of Accounting and Financial Reporting. 
International Journal of Academic Research in Accounting, Finance and Management Sciences

Vol. 8 (4), pp. 21-29, () 2018 HRMARS (www.hrmars.com)

32. Zingales, L., \& Hart, O. (2009, November). How to avoid a new financial crisis. 